\title{
Dynamics of Change in Pakistan's Large-Scale Manufacturing Sector
}

\author{
USMAN AFRIDI*
}

\section{INTRODUCTION}

Examination of structural change at the sectoral level, i.e. relationship between agriculture, manufacturing and services, is a familiar exercise. However, limited attention is paid to a detailed examination of the dynamics of structural change, particularly in the manufacturing sector. Possibly, inadequate data, coupled with a limited industrial base, have not generated sufficient interest for examining the structural changes within the manufacturing sector. We have a tendency to treat the manufacturing sector either at an aggregate macro level or at a very limited level covering only a few industries. The limitations responsible for this approach are understandable and by no means overcome. However, since with time the industrial base in Pakistan has widened and the data provided by the Census of Manufacturing Industries improved, though by no means perfected, it is time for greater emphasis on studying the dynamics of the manufacturing sector to get a deeper understanding of its behaviour, trends and directions. This study is a limited effort in that direction.

We start by examining briefly structural change at the sectoral level where the changing shares of the manufacturing sector and its two major components are examined over time since 1949-50. Next we examine the shifts in industrial investment relating to policy changes and their impact on the overall growth in investment in the large-scale manufacturing sector. We then go on to examine growth in the value added in the manufacturing sector emphasizing changes between different time periods. Next we examine size, capital intensity and capital efficiency in the sector. We then examine employment, employment elasticities, the value added and wages within the sector. In the concluding section we present a summary of our findings and suggest the possible trend of the sector.

*The author is Research Economist at the Pakistan Institute of Development Economics (PIDE), Islamabad. 


\section{STRUCTURAL CHANGE AT THE SECTORAL LEVEL}

Pakistan at independence was primarily an agrarian economy. The structural shift towards developing an industrial sector started in the ealry Fifties. In 1949-50 the manufacturing sector contributed under 8 percent of the value added in GDP. This increased to 12 percent in 1959-60 and to 15 percent in 1965-66. Thereafter almost no increase in the share was recorded for the next 10 years. From 1976-77 to 1983-84 the share increased moderately from 15 percent to almost 19 percent (Table 1). Significant increases in the share of overall manufacturing occurred in the periods from 1949-50 to $1965-66$ and from 1976-77 to 1983-84. It is worth while pointing out that in the second period, in addition to improved performance of the manufacturing sector, the coverage of the CMIs which earlier had serious shortcomings of non-response also significantly improved.

It is interesting to note that the small-scale manufacturing sector reduced its share in GDP from 5.52 percent in 1949-50 to 3.8 percent in 1970-71, whereafter it increased the share to 4.9 percent in 1983-84. The large-scale manufacturing sector on the other hand increased its share from almost 2 percent in 1949-50 to 7 percent in 1959-60 and to 11 percent in 1965-66. Thereafter the sector recorded a moderate fluctuating increase to almost 14 percent in 1983-84.

It is evident that a rapid structural transformation of the economy basically took place in the period from 1949-50 to 1965-66 and this was evident from the increasing share of the large-scale manufacturing sector in the total Gross Domestic Product.

Table 1

Change in Share of Manufacturing in GDP (at constant 1959-60 factor cost)

(Percentages)

\begin{tabular}{lccccccc}
\hline & $1949-50$ & $1959-60$ & $1965-66$ & $1970-71$ & $1976-77$ & $1982-83$ & $1983-84$ \\
\hline Share in GDP & 7.75 & 12.0 & 15.2 & 16.4 & 15.2 & 18.3 & 18.8 \\
$\begin{array}{c}\text { Share of Large-scale } \\
\quad \text { Manufacturing }\end{array}$ & 2.23 & 6.88 & 11.1 & 12.6 & 10.7 & 13.6 & 13.9 \\
$\begin{array}{c}\text { Share of Small-scale } \\
\quad \text { Manufacturing }\end{array}$ & 5.52 & 5.11 & 4.1 & 3.8 & 4.5 & 4.7 & 4.9 \\
\hline
\end{tabular}

\section{SHIFTS IN INDUSTRIAL INVESTMENT}

In 1970-71 the large-scale manufacturing sector accounted for 86 percent of total investment in the manufacturing sector. The public sector in that year contributed only 4.5 percent to total manufacturing investment.
The policy changes in the early Seventies, whereby greater emphasis was laid on public sector participation, resulted in an increase in the share of the large-scale manufacturing in total manufacturing investment. By 1976-77 the share of the largescale sector in total manufacturing investment had increased to 91 percent and of the public sector to 63 percent. For the period from 1970-71 to 1976-77 growth in investment in the large-scale manufacturing sector averaged 13.4 percent per annum (Table 2).

Table 2

Investment in the Manufacturing Sector (at constant prices of 1969-70)

(Millions Rs )

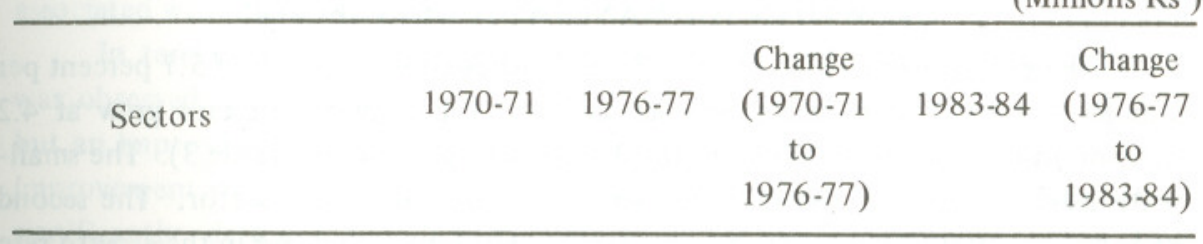

1. Private Sector

Manufacturing

1369

931

1809

2. Private Sector Manu-

facturing: Large-scale

1175

3. Private Sector Manufacturing: Small-scale

4. Public Sector Manufacturing: Large-scale

5. Total $(1+4)$

6. Public Sector as Percent of Total

7. Large-scale Manufacturing as Percent of Total 86 91 (5) 86

Growth in Investment in the

Large-scale Manufacturing

Sector 
The policy changes of the late Seventies, whereby the earlier emphasis on public sector participation was withdrawn and efforts were made to shift resources to the private sector, resulted in a decline of the share of the large-scale manufacturing sector for the period from 1976-77 to $1983-84$ to 86 percent and of the public sector to 40 percent in total manufacturing investment. Growth in investment in the large-scale manufacturing sector declined to -.2 percent per annum for the same period, a change of -13.6 percent from the previous period.

It is thus not difficult to conclude that in terms of growth of investment alone the shift in emphasis from the public to the private sector has been seriously detrimental to the large-scale manufacturing sector.

\section{GROWTH IN THE MANUFACTURING SECTOR}

The period from 1970-71 to 1976-77 witnessed low growth of 5.7 percent per annum in overall manufacturing value added. The large-scale sector grew at 4.2 percent and the small-scale sector at 10.0 percent per annum (Table 3 ). The smallscale sector performed substantially better than the large-scale sector. The second period from 1976-77 to $1980-81$ registered a substantial increase in the growth rate of the value added in total manufacturing, averaging 9.5 percent per annum. This increase was primarily due to the increase of 10.4 percent per annum in the growth rate of the large-scale sector. However, the growth rate of the small-scale manufacturing sector fell to 7.4 percent per annum in the same period.

While total manufacturing grew at the rate of 7.7 percent, the large-scale sector grew at 7 percent per annum from 1982-83 to $1983-84$ and the small scale sector at 10 percent (Table 3 ).

\section{Table 3}

Growth Rate of Value Added at Constant Prices

\begin{tabular}{|c|c|c|c|c|c|}
\hline & $\begin{array}{l}1970-71 \\
\text { to } 76-77\end{array}$ & $\begin{array}{r}1976-77 \\
\text { to } 80-81\end{array}$ & Change & $\begin{array}{l}1982-83 \\
\text { to } 83-84\end{array}$ & Change \\
\hline Total Manufacturing & 5.7 & 9.5 & 3.8 & 7.7 & -1.8 \\
\hline $\begin{array}{l}\text { Large-scale Manu- } \\
\text { facturing }\end{array}$ & 4.2 & 10.4 & 6.2 & 7.0 & -3.4 \\
\hline $\begin{array}{l}\text { Small-scale Manufac- } \\
\text { turing }\end{array}$ & 10.0 & 7.4 & -2.6 & 10.0 & 2.6 \\
\hline
\end{tabular}

Sources: [2] and [4].
It is apparent that the fall in growth in investment in the large-scale manufacturing sector in the period from 1976-77 to 1983-84 has also resulted in a deterioration of the growth rates of the value added. Moreover, the lag effect of investment on production can only result in a further deterioration in the coming years.

\section{Size, Capital Intensity and Capital Efficiency}

We have analysed size and capital intensity over the period from $1970-71$ to 1980-81. It is clear that the medium-sized establishments, which employ 250-499 workers, were the most capital-intensive in all the three periods (Table 4). This is seen in terms of $\mathrm{K} / \mathrm{L}$ and $\mathrm{V} / \mathrm{L}$ ratios. At both ends of the tables, in all the three years considered, less capital-intensive nature was observed, with the smallest size being associated with the least capital intensity.

In terms of capital efficiency, measured in terms of $\mathrm{V} / \mathrm{K}$ ratios, deterioration was observed in the case of the small-scale sector between 1970-71 and 1976-77 but an improvement in all other sectors. However, between 1976-77 and 1980-81, improvement was observed in the small and small medium sectors but other sectors significantly deteriorated. Capital efficiency on the aggregate improved from 1970-71 to $1976-77$ and declined from $1976-77$ to $1980-81$

The shares of wages in the value added, measured in terms of WL/V, declined from .37 in $1970-71$ to .24 in $1976-77$ and to $.201980-81$, the medium-sized establishments being the most seriously affected.

\section{EMPLOYMENT IN THE MANUFACTURING SECTOR}

It is interesting to note that while total employment in the manufacturing sector increased from 1970-71 to $1980-81$, the increase was much more substantial in the small-scale manufacturing sector as compared to the large-scale manufacturing sector. In the case of the large-scale manufacturing sector, employment increased from 427,411 workers in $1970-71$ to 456,761 in $1976-77$. However, the number of workers employed declined to 451,710 in 1980-81 (Table 5). On the other hand, a steady increase in employment in the small-scale manufacturing sector was recorded over the 1970-71 - 1980-81 period. The share of the large-scale manufacturing sector in total manufacturing employment declined from 17.32 percent in $1970-71$ to 14.6 percent in $1976-77$ and fell further to 12.6 percent in $1980-81$ and is projected to fall further to 11.1 percent in 1983-84. The share of employment in the small-scale manufacturing sector increased steadily from 82.68 percent in 1970-71 to 85.4 percent in $1976-77$, and to 87.4 percent in $1980-81$, and is projected to be 88.9 percent in $1983-84$. A clear structural change in the pattern of employment in the manufacturing sector of Pakistan has emerged. The share of employment in the large-scale manufacturing sector has fallen from 17.32 percent in 1970-71 to 12.00 percent in 1980-81. In the same period, share of employment in the small-scale manufacturing sector has increased from 82.68 percent to 87.4 percent. 
Table 4

Size and Capital Intensity

\begin{tabular}{|c|c|c|c|c|c|}
\hline & & $\mathrm{K} / \mathrm{L}$ & $\mathrm{V} / \mathrm{L}$ & $\mathrm{V} / \mathrm{K}$ & WL/V \\
\hline \multicolumn{6}{|c|}{$1970-71$} \\
\hline Small & 0-19 & 10045 & 8844 & 0.88 & 0.24 \\
\hline Small-medium & $20-249$ & 11244 & 9073 & 0.81 & 0.29 \\
\hline Medium & $250-499$ & 17897 & 16250 & 0.91 & 0.22 \\
\hline Medium-large & $500-999$ & 15957 & 1117 & 0.07 & 2.59 \\
\hline Large & $1000 \&$ above & 10163 & 5974 & 0.59 & 0.41 \\
\hline All Industries & & 12102 & 7154 & 0.59 & 0.37 \\
\hline \multicolumn{6}{|c|}{$1976-77$} \\
\hline Small & 0-19 & 24347 & 18451 & 0.76 & 0.29 \\
\hline Small-medium & $20-249$ & 21356 & 34298 & 1.61 & 0.23 \\
\hline Medium & $250-499$ & 33266 & 50168 & 1.51 & 0.18 \\
\hline Medium-large & 500-999 & 33758 & 42237 & 1.25 & 0.18 \\
\hline Large & $1000 \&$ above & 15309 & 23237 & 1.52 & 0.29 \\
\hline All Industries & & 21354 & 30654 & 1.44 & 0.24 \\
\hline \multicolumn{6}{|c|}{$1980-81$} \\
\hline Small & 0-19 & 29192 & 34811 & 1.19 & 0.23 \\
\hline Small-medium & $20-249$ & 40809 & 68858 & 1.69 & 0.18 \\
\hline Medium & $250-499$ & 85359 & 84359 & 1.00 & 0.17 \\
\hline Medium-large & $500-999$ & 69556 & 80165 & 1.15 & 0.18 \\
\hline Large & $1000 \&$ above & 38708 & 49916 & 1.29 & 0.23 \\
\hline All Industries & & 50295 & 63519 & 1.26 & 0.20 \\
\hline
\end{tabular}

Source: [1, for 1970-72,1976-77 and 1980-81].

Table 5

Employment in the Manufacturing Sector

\begin{tabular}{lccc}
\hline & $1970-71$ & $1976-77$ & $1980-81$ \\
\hline Large-scale Manufacturing & $\begin{array}{c}427,411 \\
(17.32)\end{array}$ & $\begin{array}{c}456,761 \\
(14.6)\end{array}$ & $\begin{array}{c}451,710 \\
(12.6)\end{array}$ \\
& & & \\
Small-scale Manufacturing & $2,040,538$ & $2,664,682$ & $3,129,198$ \\
& $(82.68)$ & $(85.4)$ & $(87.4)$ \\
Total Manufacturing & $2,467,949$ & $3,121,443$ & $3,580,908$ \\
\hline
\end{tabular}

Note: Figures in brackets show percent shares in total manufacturing. Sources: [1] and [3] - Various issues.
Share in Employment, and the Value Added by Consumer,

Intermediate and Capital Industries

The share of consumer goods industries in the value added in total manufacturing declined from 64.2 percent in $1970-71$ to 56.3 percent in 1980-81 (Table 6). It was the intermediate goods sector in the manufacturing sector that recorded a substantial increase over the period from $1970-71$ to $1980-81$, from 8.8 percent to 16.5 percent. It is pertinent to note that the increase in the share of the intermediate goods from 8.8 percent in $1970-71$ to 14.8 percent in 1976-77 was much more significant in 1980-81, when it further increased to 16.5 percent. The share of the capital goods sector in the value added increased only marginally from 17.4 percent in $1970-71$ to 18.8 percent in $1980-81$ (Table 6).

Trends in employment are not quite the same as in the case of the value added. In the case of the consumer goods industries the share of employment did not fall as sharply as value added. From a 66.5-percent share in employment in 1970-71 it fell to only 62.4 percent in $1980-81$. On the other hand, the share of intermediate goods in manufacturing employment did not increase at the same rate as in the case of the value added, increasing from 6 percent of share in total employment in 1970-71 to 7.8 percent in 1976-77 and falling to 7.6 percent in 1980-81 (Table 6). Thus though the share in value added increased from 1976-77 to $1980-81$, the share in employment fell.

In the case of capital goods, the shares of employment and value added both increased upwards marginally from 1970-71 to 1980-81. We can see that the intermediate goods sector has been the least employment-generating amongst the three sub-sectors of the large-scale manufacturing sector.

The consumer industries with a significant fall in share of value added from 1970-71 to 1976-77 did not see a significant fall in the share of employment. In the second period, 1976-77 to 1980-81. However, for the consumer industries a marginal increase in the share of value added was accompanied by a marginal fall in the share of employment.

The intermediate goods have had a different behaviour. From 1970-71 to $1980-81$, though the share in value added has almost doubled, the share of employment has only marginally increased. In the capital goods industries the shares of both employment and value added have remained almost static.

Individual industries worthy of special mention are firstly the cotton textile industry whose share in total value added fell from 25 percent in $1970-71$ to all percent in 1980-81. Share of employment in cotton textile industry fell from 37 percent in 1970-71 to 30 percent in 1980-81. In the Cement industry, though share of value added almost doubled from $1970-71$ to $1980-81$, its share in employment has remained static. In the Iron and Steel industry both the shares of value added and employment almost doubled from 1970-71 to 1980-81. 
Table 6

Share in Employment and Value Added in Consumer, Intermediate and Capital Goods Industries

\begin{tabular}{|c|c|c|c|c|c|c|}
\hline \multirow[b]{2}{*}{ Name of Industry } & \multicolumn{2}{|c|}{$1970-71$} & \multicolumn{2}{|c|}{$1976-77$} & \multicolumn{2}{|c|}{$1980-81$} \\
\hline & $\begin{array}{c}\% \text { share in } \\
\text { Employment }\end{array}$ & $\begin{array}{c}\% \text { Share in } \\
\text { Value Added }\end{array}$ & $\begin{array}{l}\text { \% Share in } \\
\text { Employment }\end{array}$ & $\begin{array}{c}\% \text { Share in } \\
\text { Value Added }\end{array}$ & $\begin{array}{c}\text { \% Share in } \\
\text { Employment }\end{array}$ & $\begin{array}{c}\text { \% Share in } \\
\text { Value Added }\end{array}$ \\
\hline Consumer Goods Industries & 66.5 & 64.2 & 64.9 & 55.8 & 62.4 & 56.3 \\
\hline Edible Oil & 1.9 & 3.8 & 2.4 & 1.1 & 2.6 & 6.5 \\
\hline Sugar & 4.6 & 8.3 & 5.4 & 11.6 & 5.8 & 9.7 \\
\hline Food Processing & 2.9 & 3.1 & 2.5 & 3.2 & 3.0 & 3.5 \\
\hline Beverages & 0.4 & 0.7 & 0.7 & 1.5 & 0.8 & 1.8 \\
\hline Tobacco Industries & 2.8 & 10.9 & 1.8 & 12.1 & 2.9 & 13.3 \\
\hline Cotton Textile & 36.6 & 24.7 & 37.5 & 15.9 & 29.9 & 10.8 \\
\hline Textiles (Other) & 11.3 & 5.6 & 10.7 & 6.3 & 11.5 & 5.1 \\
\hline Footwear & 0.7 & - & - & - & 1.1 & 0.8 \\
\hline Wood, Cork and Furniture & 0.8 & 0.4 & 0.5 & - & 0.4 & - \\
\hline Printing, Publishing \& Allied & 1.9 & 1.6 & 1.9 & .11 & 1.9 & 0.8 \\
\hline Drugs and Pharmaceutical & 2.2 & 4.3 & 1.5 & 3.0 & 2.5 & 4.3 \\
\hline Misc. Industries & 0.4 & 0.8 & - & - & - & 0.5 \\
\hline Intermediate Goods Industries & 6.0 & 8.8 & 7.8 & 14.8 & 7.6 & 16.5 \\
\hline Leather & 0.8 & 1.2 & 0.8 & 1.1 & 1.0 & 1.1 \\
\hline Paper and Paper Products & 1.5 & 1.6 & 1.7 & 1.4 & 1.8 & 1.5 \\
\hline Industrial Chemicals & 1.4 & 3.7 & 1.7 & 2.2 & 1.6 & 2.3 \\
\hline
\end{tabular}

Table $6-($ Continued $)$

\begin{tabular}{|c|c|c|c|c|c|c|}
\hline Fertilizers & 0.7 & 1.0 & 1.1 & 3.5 & 1.2 & 3.2 \\
\hline Rubber Products & 1.6 & 1.3 & 2.1 & 1.8 & 1.2 & 1.0 \\
\hline Petroleum and Coal & - & - & 0.4 & 4.8 & 0.8 & 7.4 \\
\hline Capital Goods Industries & 19.4 & 17.4 & 20.7 & 16.1 & 20.7 & 18.8 \\
\hline Cement & 1.7 & 2.6 & 1.9 & 1.7 & 1.9 & 5.5 \\
\hline Non-Metallic Minerals & 2.4 & 3.4 & 1.2 & 0.6 & 0.7 & 0.5 \\
\hline Iron and Steel & 2.5 & 2.4 & 3.7 & 3.9 & 4.0 & 4.0 \\
\hline Metal Products & 3.5 & 1.8 & 2.6 & 2.1 & 2.4 & 1.1 \\
\hline Machinery except Electrical & 2.4 & 1.0 & 3.3 & 2.2 & 3.0 & 1.7 \\
\hline Electrical Machinery & 3.2 & 3.6 & 3.7 & 3.2 & 3.7 & 3.5 \\
\hline Transport Equipment & 3.7 & 2.6 & 4.5 & 2.4 & 5.0 & 2.5 \\
\hline TOTAL & 91.4 & 90.4 & 93.4 & 86.7 & 90.7 & 91.6 \\
\hline
\end{tabular}

Source: [1], - Various issues. 
Table 7

Growth of Output and Employment and Employment Elasticities by Industrial Classification of the Large-scale Manufacturing Sector

\begin{tabular}{|c|c|c|c|c|c|c|}
\hline \multirow[b]{2}{*}{ Industrial Groups } & \multicolumn{3}{|c|}{$1970-71-1976-77$} & \multicolumn{3}{|c|}{$1976-77-1980-81$} \\
\hline & $\begin{array}{l}\text { Employ- } \\
\text { ment }\end{array}$ & $\begin{array}{l}\text { Out- } \\
\text { put }\end{array}$ & $\begin{array}{c}\text { Employ- } \\
\text { ment } \\
\text { Elasti- } \\
\text { city }\end{array}$ & $\begin{array}{c}\text { Employ- } \\
\text { ment }\end{array}$ & $\begin{array}{l}\text { Out- } \\
\text { put }\end{array}$ & $\begin{array}{c}\text { Employ- } \\
\text { ment } \\
\text { Elasti- } \\
\text { city }\end{array}$ \\
\hline Food & 2.3 & 7.1 & 0.32 & 2.1 & 7.6 & 0.28 \\
\hline Beverages & 1.3 & 19.3 & 0.07 & 4.3 & 14.8 & 0.29 \\
\hline Tobacco & -5.8 & 1.4 & -4.14 & 11.7 & 12.4 & 0.93 \\
\hline Textiles & 1.2 & 3.9 & 0.31 & -3.9 & 4.3 & -0.91 \\
\hline Wearing Apparel & 1.5 & 34.3 & 0.04 & 26.0 & 25.0 & 1.04 \\
\hline Leather Products & $0: 2$ & 9.9 & 0.02 & 5.8 & 2.1 & 2.76 \\
\hline Footwear & -10.6 & -3.9 & 2.72 & 37.2 & 51.2 & 0.73 \\
\hline \multicolumn{7}{|l|}{ Ginning, Pressing and } \\
\hline Baling of Fibres & -18.4 & -20.7 & 0.89 & 35.9 & 51.1 & 0.70 \\
\hline Wood and Cork & 2.2 & 8.1 & 0.27 & 3.1 & 24.7 & 0.13 \\
\hline Furniture & -19.5 & -10.9 & 1.79 & 11.7 & 28.9 & 0.40 \\
\hline Paper \& Paper Products & 32.8 & -1.0 & -32.8 & 1.1 & 15.2 & 0.07 \\
\hline \multicolumn{7}{|l|}{ Printing, Publishing and } \\
\hline Allied Industries & 0.8 & -1.3 & -0.62 & -0.7 & 5.2 & 0.13 \\
\hline \multicolumn{7}{|l|}{ Drugs \& Pharmaceutical } \\
\hline Products & -4.7 & 2.1 & -2.24 & 12.6 & 18.1 & 0.70 \\
\hline Industrial Chemicals & 5.7 & 8.8 & 0.65 & 0.3 & 10.5 & 0.03 \\
\hline Chemicals Products & 0.1 & 4.9 & 0.02 & 5.6 & 12.8 & 0.44 \\
\hline Petroleum and Coal & - & - & - & 15.7 & 82.3 & 0.19 \\
\hline Rubber & 6.1 & 9.0 & 0.68 & -12.6 & -1.3 & 9.69 \\
\hline Plastic Products & 5.8 & 13.8 & 0.42 & 8.4 & 10.8 & 0.78 \\
\hline Pottery, China \& Earthenware & 0.2 & 5.6 & 0.04 & 1.2 & 8.9 & 0.13 \\
\hline Glass & -6.6 & -2.2 & 3.00 & -2.1 & 8.4 & -0.25 \\
\hline \multicolumn{7}{|l|}{ Non-Metallic Mineral } \\
\hline Products & 5.9 & 3.8 & 1.55 & -4.6 & 19.0 & -0.24 \\
\hline Iron and Steel & 8.0 & 11.1 & 0.72 & 1.9 & 9.0 & 0.21 \\
\hline \multicolumn{7}{|l|}{ Non-Ferrous Metallic } \\
\hline Industries & 7.4 & -5.8 & -1.28 & 12.8 & 15.4 & 0.83 \\
\hline Fabricated Metallic Products & -4.1 & 2.4 & -1.71 & -2.9 & 1.5 & -1.93 \\
\hline Machinery & 6.2 & 15.1 & 0.41 & -2.3 & 11.6 & -0.19 \\
\hline Electrical Machinery & 3.7 & 5.7 & 0.65 & -0.3 & 15.2 & -0.02 \\
\hline Transport Equipment & 4.5 & 9.8 & 0.44 & 2.7 & 6.4 & 0.42 \\
\hline \multicolumn{7}{|l|}{ Scientific Precision and } \\
\hline Measuring Equipment & -11.5 & 3.3 & -3.48 & -1.7 & 7.2 & -0.24 \\
\hline \multicolumn{7}{|l|}{ Photographic \& Optical } \\
\hline Goods & -13.2 & -13.8 & 0.96 & 16.7 & 84.2 & 0.20 \\
\hline Sports \& Athletic Goods & 3.3 & 2.7 & 1.22 & -10.6 & 13.1 & -0.81 \\
\hline \multicolumn{7}{|l|}{ Other Manufacturing } \\
\hline Industries & -7.4 & -5.5 & 1.35 & 0.6 & 16.3 & 0.04 \\
\hline All Other Industries & -18.3 & 23.3 & 0.79 & - & - & - \\
\hline ALL INDUSTRIES & 1.1 & 5.1 & 0.22 & -0.28 & 12.1 & -0.02 \\
\hline
\end{tabular}

Sources: [1] and [2] - Various issues.
Industrial structure with an overpowering consumer goods industry and a limited intermediate and capital goods industry is definitely not conducive to industrial and economic development in the long run. For a meaningful industrial structure it is important that the share of the capital goods industries be at a significant level and as a minimum for a developing country its share should increase over time. In Pakistan, over the period from 1970-71 to 1980-81 this does not seem to have been the case. The share of the capital goods industry in fact declined. Even when we compare it with other developing countries, it is alarmingly low.

\section{Employment, Output and Employment Elasticities}

The behaviour of employment and output between 1970-71 and 1980-81 is very interesting. For the whole large-scale manufacturing sector for the sub-period from 1970-71 to 1976-77 output grew at an annual rate of 5.1 percent. In the second period, $1976-77$ to $1980-81$, it grew at 12.1 percent which was more than double the rate of the first period (Table 7). Employment however behaved differently. In the first period it grew at an annual rate of 1.1 percent and in the second period it grew at a negative rate of -.28 percent. Elasticitly of employment dropped from .22 in $1970-71-1976-77$ to -.02 in $1976-77-1980-81$. It is significantly clear that for the period from 1976-77 to 1980-81 though significant growth in output has taken place, this output has not been conducive to employment generation.

An examination of growth of output and employment and employment elasticities of major industrial groups makes an interesting picture. As is evident from Table 7 negative elasticities were significantly recorded in the second period, the most important being the textile industry which carries a large weight in the large-scale manufacturing sector. Industries such as Food, Beverages, Wearing Apparel, Chemical, Plastics and Transport equipment consistently recorded healthy growth rates of employment and output and employment elasticities over both periods.

\section{Trends in Wages}

Real wages grew at the rate of 3.4 percent per annum for all industrial workers for the period from 1970-71 to 1976-77 (Table 8). The rate of growth improved to 4.5 percent per annum in the following period, i.e. from 1976-77 to 1980-81.

In the first period, 5 industries (Gining, Pressing and Baling of Fibres, Printing and Publishing, Rubber, Electric Machinery and Photographic and Optical goods) recorded negative growth rates. In the same period Food, Beverages, Non-Ferrous Metal, Machinery and Equipment, and Sports and Athletic Goods recorded significantly high positive growth rates.

In the second period, 9 industries recorded negative growth rates, namely Tobacco, Wearing, Apparel Printing and Publishing, Drugs and Pharmaceuticals 
Table 8

Growth in Real Wages of Industrial Workers (at constant 1959-60 factor cost)

\begin{tabular}{|c|c|c|c|}
\hline & $\begin{array}{c}1970-71 \\
\text { to } \\
1976-77\end{array}$ & $\begin{array}{c}1976-77 \\
\text { to } \\
1980-81\end{array}$ & $\begin{array}{c}1970-71 \\
\text { to } \\
1980-81\end{array}$ \\
\hline All Industries & 3.4 & 4.5 & 3.9 \\
\hline Food Manufacturing & 7.7 & 2.7 & 5.7 \\
\hline Beverage Industries & 7.9 & 6.9 & 7.5 \\
\hline Tobacco Manufacturing & 5.7 & -6.5 & 0.7 \\
\hline Manufacture of Textiles & 2.8 & 4.3 & 3.4 \\
\hline Manufacture of Wearing Apparel & 3.4 & -0.2 & 1.9 \\
\hline Manufacture of Leather & 1.9 & 0.4 & 1.3 \\
\hline Manufacture of Footwear & 3.5 & 7.2 & 5.0 \\
\hline Ginning, Pressing and Baling of Fibres & -0.3 & 8.1 & 3.0 \\
\hline Manufacture of Wood & 13.0 & 5.7 & 10.0 \\
\hline Furniture & 4.6 & 9.0 & 6.3 \\
\hline Manufacture of Paper & 1.0 & 5.0 & 2.6 \\
\hline Printing, Publishing \& Allied Industries & -1.5 & -0.4 & -1.1 \\
\hline Manufacture of Drugs \& Pharmaceutical Products & ts 3.3 & -0.7 & 1.7 \\
\hline Manufacture of Industrial Chemicals & 1.5 & 7.6 & 3.9 \\
\hline Manufacture of Other Chemical Products & 3.5 & 3.6 & 3.6 \\
\hline \multicolumn{4}{|l|}{ Manufacture of Miscellaneous Products of } \\
\hline Petroleum and Coal & - & -1.7 & - \\
\hline Manufacture of Rubber Products & -6.7 & 4.5 & -2.3 \\
\hline Manufacture of Plastic Products n.e.c. & 4.1 & 8.0 & 5.6 \\
\hline Manufacture of Pottery, China and Earthenware & 3.9 & 6.2 & 4.8 \\
\hline Manufacture of Glass and Glass Products & 1.1 & 8.8 & 4.1 \\
\hline Manufacture of Non-Metallic Mineral Products & 3.0 & 7.6 & 4.8 \\
\hline Iron \& Steel Basic Industries & 6.9 & -0.8 & 3.7 \\
\hline Non-Ferrous Metal Basic Industries & 9.2 & 9.5 & 5.5 \\
\hline Manufacture of Fabricated Metal Products & 2.8 & 5.3 & 3.8 \\
\hline Manufacture of Machinery and Equipment & 8.4 & -0.4 & 4.8 \\
\hline Manufacture of Electrical Machinery & -13.8 & -4.3 & -10.2 \\
\hline Manufacture of Transport Equipment & 7.0 & 4.0 & 5.8 \\
\hline Manufacture of Scientific Equipment & 7.4 & 4.4 & 6.2 \\
\hline \multicolumn{4}{|l|}{ Manufacture of Photographic and Optical } \\
\hline Goods & -18.6 & 13.6 & -7.0 \\
\hline Manufacture of Sports and Athletic Goods & 28.4 & -29.2 & 1.2 \\
\hline Other Manufacturing Industries & 1.3 & 6.5 & 3.4 \\
\hline
\end{tabular}

Petroleum and Coal, Iron and Steel, Machinery and Equipment, Electrical Machinery, Sports and Athletic Goods.

Though no absolute clear pattern or trend emerges, it would, however, seem that industries of more capital-intensive nature and those more exposed to external dependence have been the most regressive in terms of real wage growth.

\section{CONCLUSIONS}

We have emphasized the need for examining the structural changes of and within the large-scale manufacturing sector. We have primarily used the data provided by the CMIs for this purpose. We understand that the problems of non-response have decreased since 1975-76 though the problem is still present. We would stress the need for regular surveys to check the extent of non-response. We feel, however, that the industrial base covered has grown to an extent that studies to find trends can be quite meaningful.

We have found that maximum structural change in Pakistan's economy was in the period from 1949-50 to 1965-66 when the share of the large-scale manufacturing sector in total GDP increased almost fivefold. Even if we keep in mind the small initial base, it was a healthy change.

Growth in investment in the large-scale manufacturing sector was at a healthy 14 percent per annum in the period from 1970-71 to 1976-77 and a deplorable level of -.2 percent from 1976-77 to $1983-84$. We would suggest here that one of the main factors leading to this -14.2 percent change is the -28 percent change in the share of the public sector in total investment. This fall in the growth rate of investment is reflected in the fall in growth rates of the value added in the years 1982-83 and 1983-84

We have found the medium-sized establishments to be the most capitalintensive. Capital efficiency on the aggregate improved from 1970-71 to 1976-77 and deteriorated from 1976-77 to 1980-81. The share of wages in the value added has steadily decreased over time.

We have found employment in the large-scale manufacturing sector increasing in the first period and decreasing in the second period. In our comparison of consumer, intermediate and capital goods we have found the intermediate goods industry to have had the maximum increase in the share of the value added. This group forms a major share of the medium-sized industry which we have found to be the most capital-intensive.

We have found that in terms of growth in investment, growth in the value added, decrease in capital intensity and increase in capital efficiency and growth in employment, policies contributing to an increase in the participation of the public sector are more conductive. 


\section{REFERENCES}

1. Pakistan. Central Statistics Office. Census of Manufacturing Industries. Karachi. (Various Issues)

2. Pakistan. Ministry of Finance. Economic Adviser's Wing. Pakistan Economic Survey. Islamabad. (Various Issues)

3. Pakistan. Ministry of Finance. Statistical Division. Labour Force Survey. Karachi. (Various Issues)

4. State Bank of Pakistan. Annual Report 1983-84. Karachi.

Comments on

"Dynamics of Change in Pakistan's Large-Scale Manufacturing Sector”

must confess to some feeling of disappointment on reading this paper. This disappointment stems from the author's excessive preoccupation with the task of measurement rather than interpretation. And, as I always remind my students, and more importantly myself, to meausre is not to understand. So if we are to move beyond the stage of sheer measurement to more fruitful interpretive analysis, it is essential that we learn to probe behind the data, to disentangle cause from effect, and to explain statistical trends in the perspective of events that have helped to shape the outcome. This the author has conspicuously failed to do.

The paper opens with a review of structural change at the 'sectoral level'. By this is meant the relative performance of the large-versus the small-scale manufacturing sector. The author does not apparently realize that the contribution of the small-scale sector is not a measured phenomenon. It is rather an exogenously specified constant, set equal to the rate of population growth up to the ' 70 s and pegged at a 7 percent per annum growth thereafter. Comparisons with the small-scale sector are therefore largely infructuous.

There is a section on shifts in industrial investment which is useful but insufficiently precise. Apart from a vague reference to the 'policy changes' in the ' 70 s in favour of the public sector, there is virtually no analysis of the trends in investment flows. The author concludes that the slowdown in investment in the 1977-84 period has resulted in a fall in the growth of the value added in manufacturing. Actually, Table 3 shows the reverse - an acceleration in the growth of the value added from an annual average of 4.2 percent in the 1971-77 period to 10.4 percent per year in the 1977-81 period. The author is probably referring to the 7 percent growth rate in 1984 which is below the trend rate of 10.2 percent per annum in the 1977-81 period. Clearly, however, one year's growth experience is not a sufficient basis fo making such a statement. Moreover, 1983-84 was an unusual year during which the manufacturing sector suffered from a severe setback to domestic cotton production.

This is followed by a section on size, capital intensity and capital efficiency. Table 4 is a good example of the uncritical application of data of questionable 
accuracy. There is the by-now-familiar inverted U-shape between productivity, factor intensity and the size of enterprise but no explanation for it. The data for 1970-71 show that the medium-large firms had a capital productivity of 0.07 which is absurdly low and a wage share of 2.59 , or 159 percent, of the value added. The statement that the smallest size class is the least capital-intensive is self-evident. The more interesting question is why capital intensity (and labour productivity) falls off dramatically in the higher size classes. What implications does this have for the choice of techniques and products for the underlying production function and the elasticity of substitution? How does one account for the fact that capital intensity and labour productivity in the so-called large enterprises is in some cases lower than in small enterprises? Are there serious financial, administrative and technical diseconomies associated with large size establishments in Pakistan? In which industries and why? The author claims that capital efficiency varies between different size classes and time periods without explaining why it did so. He also states that the share of wages in value added declined with the sharpest fall occurring in the medium-sized establishments. No explanation is offered for this phenomenon.

The paper then goes on to look at employment in manufacturing. Again, as I have said before, the reported change in employment in the small-scale sector is spurious. It simply reflects a change in estimation methodology. The section on employment elasticities leaves one with a sense of unease. What is one to make of an elasticity of -32.8 or 0.03 ? Clearly the time period is too short and the data subject to fluctuations and errors in variables, making estimation difficult and misleading. It is claimed that the overall manufacturing employment elasticity appears to have declined over time. No implications are drawn from this statement.

The paper finally concludes with a desultory section on real wages. None of this would seem to have relevance to the main body of the paper.

In making these comments, I hope I have not been unreasonably harsh and critical. The author has obviously laboured hard over the task of collecting and tabulating information on the structural characteristics of Pakistan's large-scale manufacturing sector. At best, however, this constitutes merely the tip of the iceberg; much more needs to be done to impart greater analytical rigour to the paper and to support the statistical material presented with well-reasoned arguments and good economic judgment.

Chief,

Dr Meekal Aziz Ahmed

Planning and Development Division,

Government of Pakistan,

Islamabad 